\title{
FLE (Français Langue Étrangère) Learning Strategies in the Light of the Neuro-Linguistic Approach
}

\author{
Rosario Pellegrino \\ Dipartimento di Studi Umanistici (DIPSUM), University of Salerno, Italy \\ Received December 7, 2019; Revised January 29, 2020; Accepted February 7, 2020
}

Copyright $(2020$ by authors, all rights reserved. Authors agree that this article remains permanently open access under the terms of the Creative Commons Attribution License 4.0 International License

\begin{abstract}
The purpose of this paper is to highlight the impact of Neuro-linguistic Programming (NLP) on the Neuro-linguistic Approach (NLA), which is the former's most natural application in the teaching field. NLA is not envisaged as a substitute for the language teaching approaches that have emerged in recent years, but aims essentially to define the so-called perceptive channels indicated by the acronym V.A.K.O.G. which underpin every form of learning and language learning in particular. On the basis of the studies of Claude Germain and Joan Netten inspired by the research of Michel Paradis into bilingualism, the principle of littératie (information literacy) is adopted in order to establish the relationships between harmony and anchoring, and between the communicative approach and NLA. References and studies on neurological pathologies find that declarative memory and procedural memory follow different processes and that knowledge and ability follow distinct cerebral paths. Harmony between individuals and anchoring to subjective elements lead researchers to set up efficacious and long-lasting learning paths.
\end{abstract}

Keywords NLP, NLA, Procedural Memory, Declarative Memory, Littératie (Information Literacy), Anchoring, Perceptive Channels

\section{Introduction}

Neuro-linguistic programming enjoyed a period of great interest and development before sinking into oblivion, at least as regards its application to language teaching. True to the spirit of its founders Bandler and Grinder (1975), NLP promoted psychological approaches as alternatives to traditional ones and aimed at integral and dynamic personal development in a collective or team perspective both at work and in a more psychotherapeutic context. Starting from the construct to remove a negative experience, above all one of the many phobias that afflict the whole human race, the person in question relives the experience in a sort of psychodrama as a spectator, protagonist and director all at the same time, thus implementing the so-called double dissociation (Bandler, 2004). Far from acting as a substitute for psychotherapy, NLP is characterized as a simple and not markedly scientific approach that starts from the assumption that certain automatisms do not change from individual to individual in a given context because what changes are the gestures closely related to thought. The real changes lie in human psychological behaviour achieving what is commonly referred to as adaptation to external conditions. This assumption has probably sanctioned the success of NLP at least in specific contexts and has impacted different areas in which human behaviour is the protagonist. NLP aims specifically to contextualize each previously determined and eventually achieved result. NLP sees such behaviour as being underpinned by a programming of behaviour rooted in the learning concept.

L'aspect programmation de la PNL est basé sur l'idée que les processus d'apprentissage, de mémorisation, et de créativité de l'humain sont une fonction de programmes neuro-linguistiques qui fonctionnent plus ou moins efficacement pour accomplir des objectifs spécifiques. Le résultat, pour les êtres humains, est qu'ils interagissent avec le monde qui les entoure au travers de leur propre programmation. Chaque humain répond aux problèmes et approche de nouvelles idées en s'accordant au type de programmes mentaux qu'il a établi - et l'ensemble des programmes ne sont pas égaux. Certains programmes ou stratégies sont plus efficaces pour accomplir certains types d'activités plutôt que d'autres. Il y a des liens entre la PNL et d'autres courants de la psychologie car la PNL se dessine à partir de la neurologie, de la linguistique et des sciences cognitives (Dilts \& Delozier, 2000).

Linguistics is thus one of the building blocks of NLP and, as we have seen, it is closely linked to the concept of 
learning which gives rise to reactions and attitudes that adapt to external conditions. The mediation between brain activity and attitudes adopted by the individual is attributed to the perception and the sensory channels that constitute the basic driving mechanism. Indeed, every relationship between an individual and the outside world must necessarily pass through the five senses, which appear to be differently developed in each person but one sensory channel for learning is certainly privileged. The manifestation of human actions is therefore affected by the five so-called V.A.K.O.G. communication channels (Visual, Auditory, K-kinaesthetic, Olfactory, Gustatory), none of which is more important than the others nor is there a hierarchical relationship between them.

\section{From Harmony to Anchoring}

NLP focuses on the value of harmony between individuals, from which a further basic concept for the theory and the learning of languages derives. In other words, sharing similar gestures and attitudes establishes a process of synchronization or empathy based on a balance of power and the absence of dominant positions which might tend to distort the exchange. This mutual acceptance fosters relationships and exchanges between the two people and can, in turn, generate forms of learning mediated by verbal or non-verbal language. By making use of man's spontaneous and innate ability to relate to others, both parties are encouraged and empowered to learn by means of footholds and references to concrete external data. This is known as the anchoring phenomenon (Squirrel, 2008), which essentially consists of a spontaneous and natural process associating an internal emotional state with an external sensory stimulus. The learning process, and especially language learning, is the consequence of anchoring, i.e. the subsequent and often definitive association arising from the first process established. After an initial association between the internal and the external stimulus, it is sufficient for the individual to receive the stimulus so that the associated response and the resulting experience emerge from memory to become part of the person's/learner's memory resource and sensorial experience. A concrete example will help us understand the scope of this and perhaps open up new horizons: Proust's 'madeleine moment', by itself, manages to explain the extent to which the combination of different experiences brings to mind past experiences and resources that can foster effective and long-lasting learning. Many teachers have found that combining learners' desires and needs with external and sometimes paradoxically connected concepts can help make the process of acquiring a foreign language both pleasant and natural. The concept of association of ideas was assimilated by NLP, which established the need to view it as a conscious process through which our brain learns and remembers extremely quickly. For NLP, the so-called enchaînement d'ancrages (accumulation of associations) gives rise to the enchaînement de pensées which, in addition to therapeutic applications, certainly has useful implications for the language learning phase as it fosters and accelerates progress along the learning path. The effect is amplified if and when the concepts are associated with sensory experiences, such as smells or tastes. In this case there is a sort of reinforcement that makes the sensory experience and the learning more effective and longer-lasting (Dilts, 1999).

Une bonne manière de débuter la compréhension de l'usage des ancres est de se demander comment elles peuvent être utilisées dans l'enseignement et l'apprentissage. Le processus d'ancrage est, par exemple, un moyen efficace de consolider et de transférer des expériences d'apprentissage. Dans sa forme la plus simple, l'ancrage nécessite d'établir une association entre un élément externe ou stimulus et une expérience interne ou état, comme dans l'exemple de Pavlov qui faisait sonner la cloche pour ses chiens. De nombreux apprentissages dépendent de conditionnement et le conditionnement dépend du type de stimulus attaché à la réaction. Une ancre est un stimulus qui est associé à l'expérience apprentissage. Si vous pouvez ancrer quelque chose dans l'environnement d'une classe, vous pourrez utiliser l'ancre dans l'environnement de travail comme rappel associatif de ce qui a été appris (Dilts, 1999).

The assumption is clear and linear: Dilts recommends anchoring any stimulus, or at least the most difficult ones, to well-defined concepts for longer-lasting learning. The experiment he reports is useful for the investigation because when a group of learners is assigned a tâche and is then divided into two separate groups, the best results are reported by those who remained in their class of origin. $\mathrm{He}$ claims that the reason for this is that those learners had continued to have the same reference points in the classroom and with their classmates, while the other group reported worse results because they had lost them. Evidently ancrage is an act that is neither predictable nor, moreover, adaptable to every situation. The association process requires certain conditions to exist, such as a focus on the learner's consciousness and the creation of connections between experiences in order to enrich meanings or, alternatively, consolidate and transfer knowledge and experience to other contexts, in line with the latest methodological approaches. Dilts also expresses his fundamental belief in a new approach to cognitive knowledge regarding the inner workings of the learner's mind. This is the novelty of anchoring: the rediscovery of links between things and sensations that, once internalised, succeed in rooting learning and creating more effective and personalized methods and approaches (Dilts, 1999). But which anchors ${ }^{1}$ have the greatest impact on learning?

1 An anchor is the set of signals that foster the transfer of learning from 
According to the author, they are "celles pour lesquelles le stimulus est en dehors de la conscience" (Dilts, 1999) which he defines as ancres cachées. As these refer to the sphere of unconsciousness, they are spontaneous and can represent forms of learning in which the person does not concentrate and is unaware of the learning process. Instead, the learner behaves naturally and proceeds according to spontaneous patterns that guarantee learning and language acquisition. This takes place without any references to metalanguage or to any explanatory or explicit reference to the learning process.

It goes without saying that even a spontaneous act like the one described above takes time in order to produce the desired effect. NLP advocates a careful and constant observation of the learner's response to the stimuli provided, mindful that context is fundamental but also that individuals are not robots and do not give similar or even equivalent responses to the same stimuli. It is no coincidence that numerous self-study courses with the goal of learning to learn, such as coup de pouce en français, ${ }^{2}$ turn to NLP in order to acquire valid FLE learning techniques. The objectives of the course in question, not unlike those of other similar sites, are to provide tools that foster an understanding of the learning process and manage the emotions in order to improve communication and learning. All this helps to interact with others through one's own structured model of the world because one of the NLP postulates is that la carte n'est pas le territoire.

\section{From the Communicative Approach to NLA}

Officially the neuro-linguistic approach (NLA) dates back to 1997 and refers to the work of Claude Germain and Joan Netten. This followed on from Paradis's studies on bilingualism (1994) which, in turn, drew inspiration from the concept of social interaction postulated by Lev Vygotsky (1978). Subsequently, or rather during the last decade, the rapid development of new and sophisticated technologies has accelerated studies on neuroscience which have furthered understanding of how the brain works and related applications in the field of learning and communication (Huc \& Smith, 2008). Paradis inaugurates a new season and provides many points for consideration by dispelling the false myth of direct links between explicit knowledge (lexical, grammatical and orthographic aspects) and procedural knowledge (aspects of prosody and verbal and phonetic spontaneity):

implicit competence, governed by the procedural memory, and explicit knowledge, retained in the declarative memory, are two distinct aspects of neuronal functioning; there is no direct connection between the two. If there were a direct connection, then simply knowing the rules of a language would enable an individual to speak the language, and being able to speak the language would imply that the individual possessed knowledge of the rules of the language. And (3) explicit knowledge does not 'transform' into implicit competence, the ability underlying spontaneous communication. If this were not the case, then people suffering from some types of aphasia would also suffer from symptoms of Alzheimer's disease with respect to the degree of impairment of their L1 and L2 (Netten \& Germain, 2012).

The exercise $=$ learning automatism is better defined and above all clearly distinguished for spoken and written language in terms of L2 learning. Traditionally and even in the communicative approach, it was believed that written language activities could spontaneously translate into procedural knowledge in the oral language, whereas NLA establishes different approaches to writing and speaking. For example, speaking is developed through specific techniques that exclude the constant and systematic use of the written text, albeit with a focus exclusively on contextualization and not on the document. Clearly the central feature of the learning approach is not based on linguistic reflection, but on the message communicated. The morpho-syntactic aspect is always contextualized in the presentation of authentic texts aimed at similar communication (Takeuchi, Kageura \& Takahashi, 2016). This results in what is called "littératie", i.e. the ability, confidence and willingness to interact through language in order to acquire, build up and communicate a meaning in its everyday implications, obviously in light of the fact that language is first and foremost the result of a vast communication system made up of socio-cultural factors. ${ }^{3}$ By overcoming the traditional belief that littératie consists of the written language/spoken language binomial, new perspectives will help to contribute to an extension of the concept as an aptitude to discover the world through the achievement of excellence (Borzacchiello, 2018).

\section{Learning through «Neuro-Linguistic» Strategies}

In order to exploit the excellence that each individual can achieve, it is important to remember a fundamental principle of NLA according to which everyone succeeds well in a particular activity and can develop new competences starting from individual successes by transferring them to different contexts and situations. This

3 Retrieved from Alberta Education, https://education.alberta.ca/litt\%C3 \%A9ratie-et-num\%C3\%A9ratie/litt\%C3\%A9ratie/everyone/cest-quoi-lalitt\%C3\%A9ratie/ 
can be accomplished through a very specific number of strategies that enable the implementation of the faculty of turning to excellence, i.e. recovering the positive moments in which one has succeeded in carrying out a task or has unexpectedly found an optimal solution.

The so-called learning micro-strategies ${ }^{4}$ which entail short and rapid sequences of mental operations in response to external stimuli, are essentially as follows: memorization, comprehension, transference, reflexive strategies, utterance and communication. For instance, the first category includes the involvement of kinaesthetic experience so that the learner is able to perform operations such as the transcription of a sentence that (s)he would not, otherwise, be able to perform. The transition from the digital to the analogue visual envisaged by the micro-strategy of comprehension is extremely relevant. In light of the massive impact of new technologies, this operation is of particular importance for research. It entails the teacher asking the learner to create analogical images starting from the questions that (s)he asks about the so-called digital visual. The teacher / facilitator can invite learners to view an image with the respective name in French, e.g. table, and then to think about the image of the visualised term. This leads on to a dialogue guided by the teacher on the characteristics of the "table", e.g. the material, the colour, the size, the use, other possible uses and so on. Evidently the mental creation of the image not only helps to assimilate the lexis but, above all, develops discursive ability, the use of interrogative and negative sentences, and the position of terms and structures without, however, reflecting on the language through the use of meta-language. Robert Dilts defines this process as "ancrage":

Pour la PNL, «l'ancrage» fait référence aux processus d'association entre une réponse interne à un déclencheur externe ou interne, de façon à ce que la réponse puisse être rapidement et parfois discrètement retrouvée. L'ancrage est un processus qui, en apparence, est proche du conditionnement utilisé par Pavlov pour créer un lien entre le son d'une cloche et la salivation des chiens. En faisant une association entre le son de la cloche et l'action de nourrir les chiens, Pavlov découvrit qu'il pouvait ne faire sonner que la cloche pour obtenir la salivation du chien, même si aucune nourriture n'était donnée. Selon le schéma béhavioriste du conditionnement par stimulus-réponse, le stimulus est toujours un événement de l'environnement et la réponse est toujours une action comportementale spécifique. L'association est considérée comme réflexe et n’est pas

4 Pour rappel, une micro-stratégie est une séquence d’opérations mentales qui se déroulent dans un laps de temps court (de 2 secondes à 3 minutes). Par exemple, lorsqu'on vous dit une phrase, combien de secondes vous faut-il pour la comprendre? Cinq micro-stratégies sont décrites ici: stratégie de transfert, stratégie de compréhension, stratégie de mémorisation, stratégie de réflexion, stratégie de prononciation. (Thiry, 2012, p. 55). l’objet d'un choix (Dilts, 1999).

Micro-strategies are located within macro-strategies coinciding with learning methods proper which envisage different operations and the achievement of a very precise objective. This takes place through a process that activates procedural memory and is thus able to transfer the elements of learning into the long-term memory which stores them and makes them available for an unlimited period of time. Macro-strategies include those codified by Alain Thiry: homework, revision of texts and schooling. The use of concepts, gestures or habits to which learning methods can be "anchored" are additional strategies that can be used: each student can identify his/her own concepts which are almost ritually needed to fix linguistic data. It is important to remember that the facilitation of the language learning process can in no way replace the identification of personal strategies that each learner must find in order for the learning to be long-lasting. Following others' procedures would constitute non-original and, therefore, non-lasting fixing phases. According to neuro-linguistic theories, learners possess potential and resources that they are often unaware of. For this reason, the teacher/facilitator must endow them with procedures so that they can learn to learn, and then set in motion the learning strategies that each learner gradually discovers within themselves. In NLA the teacher is assigned the task of encouraging, organising and guiding the student to identify his/her potential and make use of it for an informed use. This is the role of NLP: to achieve communication according to defined models of excellence. The integral development of the person includes the discovery of personal resources and the strengthening of communication as a fundamental act for learning and, above all, for L2 acquisition.

The application of NLP to language acquisition involves recognising that everything in the universe is communication and that each individual cannot fail to communicate. However, communication becomes meaningful only if results are obtained or feedback is received because this is the data on which to base learning through perceptive channels, whether privileged or not. These results underpin the search for every form of interaction underlying every learning approach. In communication, each speaker never establishes a univocal relationship but implements the so-called "retro-action" in which each individual involved learns both from the other interlocutor, and from his/her forms of communication: verbal, non-verbal or paraverbal. This assumption helps to understand the weight of the network of relationships and communication that any human contact involves. The learner as a carrier of beliefs, culture, behaviour, skills and relationships can promote or prevent a correct relationship for language acquisition. Robert Dilts defines an individual's patrimony as “niveaux logiques”. They represent strengths to help overcome the obstacles that prevent the achievement of excellence or of a conscious and correct use of structures, terms and expressions/idioms. 
The levels are linked together and constitute obligatory steps: from the environment to behaviour and from ability to identity, the highest level of awareness, and once this has been reached, the transformation can begin for a positive or negative response to learning generally. The process is complex and requires the application of a concept postulated by Guy Missoum, La PNL appliquée (1996, pp. 66-67), which states that fostering authentic communication with another learner entails the establishment of a relationship characterised by complete harmony and participation of the various communicative components in which imitation assumes a major role. For instance, learners may sometimes imitate their teachers' gestures and speech unintentionally. Synchronisation can be both verbal and non-verbal. The former, through the so-called calibrage process, involves the partial or total reproduction of elements belonging to the visual, auditory and kinaesthetic areas. ${ }^{5}$ The result is not at all an automatic act. It envisages a sort of decoding based, in turn, on various forms of communicative adaptation, through which the individual constructs a representation and experiences the immediate environment according to his/her perceptive channels; indeed, according to NLP, each individual has a privileged perceptive channel. Access to the thoughts of one with whom contact is made occurs solely through these sensory or perceptive channels which determine lexical choices, gestures, tone, rhythm and expressions, i.e. the particular elements of any given person.

In order to ensure FLE acquisition, the various perceptive channels should be used to facilitate a constant transfer of knowledge and existing skills as well as those acquired in the light of the concepts expressed and summarized in niveaux logiques, synchronization, calibrage and anchoring. Adaptation to the communication of others and to their models of world representation helps not only to make the memorization of linguistic elements faster and longer-lasting but also to make the learner aware of his/her potential. Consequently, it can be suggested that an appropriate use of NLP techniques will very probably help to acquire the complex structures and many complicated verb forms of French more quickly and without the use of metalinguistic rules and forms that often mislead the learner. This may happen for any number of reasons but above all it is due to the lack of structural knowledge of their own mother tongue. The use of anchoring to facts and concepts apparently unrelated to the term/concept being learned can motivate the learner by achieving the primary objective of the NLA. The teaching/learning of languages at school and university could benefit from the application of neuro-linguistic techniques in order to promote both spontaneous and rooted forms of communication at the same time so as to

5 The reference is to the system defined by NLP, VAKOG: Visual, Auditive, Kinaesthetic, Olfactory and Gustatory. overcome resistance to the learning process.

Monique Esser, the undisputed authority in the French language field of NLP, claims that «le modèle du monde d'une personne est l'ensemble des représentations mentales qu'elle construit pour se représenter ses expériences» ${ }^{6}$. The basic concept is that the map is not the territory but that each person is called upon not to affirm his or her own map but to consider other people's maps so as to broaden their horizons and arrive at a representation of the French language that corresponds to the real spoken and written language, without disregarding the learner's constructs. According to Esser, this would facilitate «un dialogue beaucoup plus fécond si on travaillait sur cette différence plutôt que de travailler à l'affirmation de sa propre carte» ${ }^{7}$. The relationship between the different maps and the lack of direct relationship between knowledge (declarative memory) and ability (procedural memory) (Genesee, Paradis \& Crago, 2004) suggest different teaching practices which we will refer to in order to better explore the NLA world.

\section{NLA and DELF Compared}

The neuro-linguistic approach constitutes a new educational paradigm, above all because it does not focus attention on language content to be acquired but, rather, on the so-called memory contents, which means that priority is given to learning and not to the teaching process. This overcomes the inseparability of the two concepts affirmed by most approaches in recent decades. It is no coincidence that NLA promotes littératie, that is the ability to make critical use of language and images in order to read, listen, see and represent. The production of meaning through the interaction of individuals is fundamental for littératie and the first major obstacle that NLA encounters is the achievement of DELF's objectives linked above all to more traditional strategies; essentially these are the four language skills (listening, speaking, reading and writing) as well as those of social interaction - which are not always compatible with the new neuro-linguistic approach. A working group made up of the FLE scholars Claude Germain, Romain Jourdan-Ôtsuka and Galdys Benudiz recently published the Manuel de français langue seconde selon l'Approche neurolinguistique (ANL) which complies with the precepts of the neuro-linguistic approach but offers an interesting perspective on DELF preparation to learners from all over the world. Matching the needs to overcome DELF and the activities potentially laid out in

6 Interview by Antoine Perraud, on "Tire ta langue!", France-Culture 30th March 2006. 2 Retrieved from http://www.institut-repere.com/PROGRAMMATION-NEURO-LINGUI STIQUE-PNL/institut-repere-ressources-documentaires-monique-esser-p arle-de-la-pnl-sur-france-culture-31052006.html 7 Ibidem. 
NLA entails adapting teaching units, redirecting attitudes aimed at overcoming DELF on the part of teachers, and modifying lesson content, oral interaction and the very structure of a French language course tout court (Claude, Jourdan-Ôtsuka \& Benudiz, 2018). The study shows how NLA enhances the language acquisition process by providing valid tools to define new paths for its achievement but its relationship with assessment, which underpins any and every form of linguistic certification and specifically DELF, has yet to be determined. The CEFR (2001) makes no explicit references to littératie or to its related concepts, which does nothing to help reconcile the two schools of thought in question. However, it should be noted that the CEFR principles do not exclude those proposed by NLA, and the research group states that: «L'ANL et le DELF paraissent tout à fait complémentaires dans la mesure où les deux ont pour objet les capacités de communication» (Germain, Jourdan-Ôtsuka \& Benudiz, 2018). Contrastive analysis of NLA with tools for assessing French language competence has highlighted some weaknesses of the neuro-linguistic approach in terms of concrete application aimed at assessment. For this reason, the research group has trialled new forms of FLE acquisition, especially with regard to reading. The manual that emerged from a systematic and on-going study of NLA application is a concrete response to the specific needs of current FLE teaching: the authenticity of documents and communication and the diversification of the target, not least that of adult workers seeking permanent training, professional requalification or re-training. Apart from the results that can be determined only after a phase envisaging monitored use of the method, there remains the attempt of experts who have broken new ground in the application of an approach no longer in extemporaneous perspectives determined subjectively but applicable to international certifications: the cutting-edge tools of the last two decades. The scope is far from negligible given that NLA has novel features compared to NLP in that it focuses on the L2 learning process for eminently communicative purposes. Courses set up in line with modern criteria, which in some countries are inadequate given the number of hours dedicated to L2 teaching/learning and the scarce attention paid to spontaneous L2 interaction and their focus on mostly written exercises and activities, have yielded uncertain results. Consequently, serious reflection is needed so that the study of languages is increasingly aimed at the clear and definite acquisition that allows learners to understand and express themselves in a natural and relatively straightforward way.

\section{Practices for Teaching FLE in the Light of NLA}

It is no coincidence that the objectives of courses based on NLP and NLA necessarily include a verification of the linguistic competences acquired even though they do not envisage the same learning and assessment paths as better known approaches. For instance, the course promoted by the Portail Formation Interrégional Emploi for teachers aiming to acquire the neuro-lingual approach teaching qualification in the field of L2 or foreign language learning. ${ }^{8}$ This course offers teachers the possibility to acquire the epistemological principles of NLA and to experiment with learning paths in the light of shared educational choices that can be adapted to different contexts. Clearly, NLA assumes that individuals' learning times and needs are different, which means that teachers must be able to guide learners in making the best choices and following the best paths so as to optimize language acquisition. Particular attention is paid to the crucial steps, including littératie and pédagogie du projet which, in turn, aim to implement the interactive approach in which speaking is fundamental. Grammar, which has typically been neglected by some approaches, is also proposed in an exclusively contextual framework. The final Module envisages initiation into written production, a hurdle which is often underestimated and not always addressed with due care. Collaborative production is recommended and, indeed, is considered essential for drafting a personal text. This proposal could not lack a final reflection on the enjeux didactiques because of the opportunity NLA provides to transfer knowledge and develop competences starting from purely communicative skills. Although this course does not introduce major theoretical innovations, it has the merit of distinguishing speaking from writing in an interactive perspective whose sole objective is global L2 acquisition. Obstacles like individual written production, mediated by collaborative production which is more comforting and motivating, the realisation of the importance of the complete sentence and overcoming the logic of the syntagma or bias in favour of one communicative unit are significant moments that could be useful for language teachers of any educational context. What appears to be useful, although it is not an exclusively NLA prerogative, is the final phase, namely l'adaptation à votre contexte, which takes place in a perspective of activity and adaptation to extremely varied contexts, albeit united by a single objective.

Grammar is dealt with in a course open to teachers and learners called Grammaire interne \& Grammaire externe, ${ }^{9}$ whose authors Olivier Massé and Vi-Tri Tuong address simple questions to their audience so as to encourage them to reflect on L2 learning processes and not focus attention solely on the internal and external grammar concept. One

8 http://www.intercariforef.org/formations/formation-initiale-en-fle-a-lap proche-neurolinguistique-anl/anl-formation/formation-04_A820591_822 20.html

9https://www.universitesdefrancophonia.com/lapproche-neurolinguistiqu e-dans-lenseignement-du-francais-partie-ii.html 
of the questions posed "faut-il vraiment enseigner la grammaire pour faire apprendre une langue étrangère?” concerns the maitrise of the language, that is whether the mastery that a learner achieves is in some way related to the morpho-syntactic teaching/learning of the L2.

Starting from concrete data, the study reports the following results: there is an increasing dropout rate in the study of the French language; the success achieved in the FLE learning assessment examinations does not correspond to effective communication skills; a great many people with little or no schooling nevertheless manage to express themselves in languages other than their own. Massé and Truong started out from these positions in order to analyse and compare errors in the written and spoken language, and concluded that errors in spoken language (on average about $75 \%$ ) differ considerably from those in written language (on average 25\%). ${ }^{10}$ The paradox reported by scholars concerns the number of speakers of a foreign language who do not know the grammar rules and who are far more numerous than people who know the morphology of a language but are unable to communicate in that language (Paradis, 1994; Germain \& Netten, 2011).

Studies on neurological pathologies point out that declarative and procedural memory follow different procedures and that knowledge and abilities follow distinct brain pathways. ${ }^{11}$ The authors speak of two interacting networks: declarative memory is when conscious production is activated, while procedural memory is activated when referring to specific skills, such as phonetics or morpho-syntax. The former regards knowledge, the latter ability. This is where the division between internal grammar (procedural memory) and external grammar (declarative memory) comes into play. The first involves an unconscious use of the rules and pertains to the spoken language, the second to the conscious use of the rules learned and applied to written production. The study essentially emphasizes the fact that during the learning phase of a second or a foreign language the student cannot resort to internal grammar, unlike the native speaker who has a wealth of neuronal interconnections enabling access to a series of so-called implicit and unconscious information. This can be clearly seen, for example, in the formulation of a common phrase whose structures are unknown to the speaker: "il est nécessaire que je fasse mes devoirs”, which may be uttered by a French speaker who does not know how to form and use the subjunctive.

The discussion presented to the students involves watching a short, four-minute video followed by these three questions:

10 The analysis was conducted on the tests of Japanese students taking the DELF B2 qualification according to CEFR.

11 The data refer to research on bilingual patients with Alzheimer's disease or aphasia.
1) Quelles sont les étapes de la séquence pédagogique proposée?

2) Quelles interactions sont mises en place? Pourquoi selon vous?

3) A quel moment d'une unité didactique complète situeriez-vous cette phase? Pour quelles raisons?

The learners have to observe:

1) Le nombre de structures langagières manipulées.

2) Le recours à des questions ouvertes.

3) Les justifications formulées par les étudiants.

Interventions during the guided debate evidently serve to establish connections between mental processes and language learning phases with constant references to what the study defines as the NLA key words:

1. MODÈLE : Partir d'un modèle langagier. 2.INTERACTIONS : Faire acquérir le modèle par des interactions entre les apprenants. 3. AUTHENTIQUE : Créer des situations de communication authentiques. 4. GRAMMAIRES : Enseigner les 2 grammaires (habiletés à l'oral et savoirs pour l'écrit). 5. LITTÉRATIE : Viser le développement de la littératie (pour l'écrit). 6. PROJETS : Recours à la pédagogie de projet (TAP + inscription sociale) $)^{12}$.

The course has successfully restated the importance of spoken language and the dual function it performs in the learning/teaching of a second or foreign language: l'oral pour l'oral e l'oral pour l'écrit. The centrality of the spoken language not only allows the development of the communicative sphere regardless of the rules learned, but also enhances formal correctness in the written language, which the learner acquires through knowledge recalling the skills acquired in the spoken language and not vice versa.

The role of grammar is, therefore, to support communication by representing different aspects of the language acquisition process and assume an increasingly communicative role so as to foster communication and achieve encouraging and motivating results for learners. Only through the harmonisation of teaching approaches aimed at acquisition and not only reflection on the second or foreign language will it be possible to try out alternative paths whose objective remains communication in a broad sense and not linked to the individual tâches carried out.

There are two fundamental principles which can inspire correct communication: l'aisance and la précision. The former requires the teacher-facilitator to constantly interact with students by asking them to formulate complete sentences, while the latter requires the teacher-facilitator to intervene by proposing the correct sentence so that learners can acquire it. Further simultaneous strategies act alongside the two main ones, namely an appropriate

12Retrieved from//C:/Users/Utente/Desktop/PNL\%20E\%20FLE/lenseig
nement_de_la_grammaire_du_point_de_vue_neurolinguistique_-_o.mas se_-vt._truong_2016.pdf 
stimulus to listening and the intervention of the learner group in support of the struggling speaker. At this point the teacher's intervention entails summarising and specifying the peer-to-peer dialogue's more or less obvious information, which can be used to impact both the declarative and the procedural memory. It is essential that the strategies be proposed consequentially in a fixed order: modélisation of the sentence, questionnement of the learners and adaptation of the sentence to their own experiences, presentation to the class of the model sentence by two learners, questionnement mutuel or pairwork on the presented sentence and teacher intervention with questions about their partners answers (Massé, 2018: 60).

\section{Conclusions}

The neuro-linguistic approach does not claim to replace other language teaching methods as it merely offers cross-cutting methodological suggestions founded on an NLP-based approach. The picture is thus quite clear.

As stated in the introduction, the NLA proposal entails defining the so-called perceptive channels indicated with the acronym V.A.K.O.G. (Visual, Auditory, K-kinaesthetic, Olfactory, Gustatory) which underpin every form of learning and language learning in particular, valorising littératie and the distinction between declarative and procedural memory.

The main problem lies in the integration of this assumption with the different language teaching approaches, as confirmed by research on the contribution that NLA is able to bring so that they can both proceed towards a natural and spontaneous learning of the language to which learners are exposed according to the indications above all concerning the CEFR tasks. What is missing, however, is a pragmatic explanation, also at a didactic level, of what actually characterizes NLA in its choices of semi-authentic or authentic teaching documents and interventions aimed at effective language learning. The cases reported are mostly intended for teachers and there are still no readily available manuals to help the teacher decide on the educational path to follow. The strategies are clear, the objectives are defined, what is probably missing are attested experiences and structured courses that try out the approach and publish their results.

However, the observed experiences suggest that interest in NLA may have positive effects and can greatly benefit the creation of alternative paths for a correct approach to the study of FLE. The publication of further manuals based on NLA will be able to support FLE teachers by providing alternatives to the better known and regularly used stages, so as to achieve better results in which communication will be confirmed as the primary objective of the individual learning processes (Germain, Jourdan- Ôtsuka, Benudiz, in press).

\section{REFERENCES}

[1] Alberta Education. C'est quoi la littératie?. [Online] Retrieved from https://education.alberta.ca/litt\%C3\%A9rat ie-et-num\%C3\%A9ratie/litt\%C3\%A9ratie/everyone/cest-q uoi-la-litt\%C3\%A9ratie/

[2] Bandler R. (2004) Peurs, phobies et compulsions. Chabreloche (Fr): La Tempérance.

[3] Bandler R., Grinder J. (1975). The structure of Magic Tome 1 - Science and Behaviour Books. Inc. Palo Alto (CA).

[4] Bandler R., Grinder J. (1976) The Structure of Magic Tome 2 - Science of Behaviour Books. Inc Palo Alto (CA).

[5] Borzacchiello P. (2018). PNL per l'Eccellenza Linguistica, Come usare le parole giuste nel giusto ordine, Unicomunicazione. [Online] Retrieved from https://www.a mazon.it/leccellenza-linguistica-parole-giuste- giusto/dp/88 33620263

[6] Conseil de l'Europe. (2001) Conseil de l'Europe, Cadre européen commun de référence pour les langues : apprendre,

enseigner, évaluer. [Online] Retrieved from https://rm.coe. int $/ 16802 \mathrm{fc} 3 \mathrm{a} 8$

[7] Coup de pouce en Français. Retrieved from https://lewebpe dagogique.com/blocagesenfrancais/pnl/

[8] Dilts R. (1999). L'ancrage en PNL. [Online] Retrieved from http://www.institut-repere.com/PROGRAMMATION-NE URO-LINGUISTIQUE-PNL/institut-repere-base-documen taire-lancrage.html

[9] Genesee, F., Paradis, J., \& Crago, M. B. (2004). Communication and language intervention series. Dual language development \& disorders: A handbook on bilingualism \& second language learning. Baltimore, MD, US: Paul H Brookes Publishing.

[10] Germain C., Jourdan-Ôtsuka R., Benudiz G. (2018). Développements récents de l'approche neurolinguistique (ANL). Retrieved from https://www.academia.edu/371354 16/D\%C3\%A9veloppements_r\%C3\%A9cents_de_lapproc he_neurolinguistique_ANL

[11] Germain C., Jourdan-Ôtsuka R., Benudiz G. (in press). Manuel de français langue seconde ou étrangère selon l'approche neurolinguistique (ANL), Longueil: Myosotis Press.

[12] Germain C., Netten J. (2011). Impact de la conception de l'acquisition d'une langue seconde ou étrangère sur la conception de la langue et de son enseignement. [Online] Retrieved from https://www.gerflint.fr/Base/Chine6/germa in.pdf

[13] Huc, P. \& Vincent Smith, B. (2008), Naissance de la neurodidactique. Le Français dans le Monde, 357, 30-31

[14] L'approche neurolinguistique dans l'enseignement du Français. Partie II. [Online] Retrieved from https://www.u niversitesdefrancophonia.com/lapproche- neurolinguistique -dans-lenseignement-du-francais-partie-ii.html 
[15] Le portail Interrégional Formation Emploi: Des ressources et des outils au service des acteurs et des professionnels. Website : http://www.intercariforef.org/formations/formati on-initiale-en-fle-a-lapproche-neurolinguistique-anl/anl-for mation/formation-04_A820591_82220.html

[16] Massé O. (2018). La révélation ANL. Le français dans le monde, 417, 60, mai-juin 2018.

[17] Massé O., Truon V.- T.. (2016). L’enseignement de la GRAMMAIRE du point de vue neurolinguistique. Retrieved from file:///C:/Users/Utente/Desktop/PNL\%20E \%20FLE/lenseignement_de_la_grammaire_du_point_de_v ue_neurolinguistique_-_o.masse_-vt._truong_2016.pdf

[18] Missoum G. (1996). La PNL appliquée : Sport, entreprise, école, santé, politique.... Paris : Vigot. pp. 66-67.

[19] Netten, J. \& Germain, C. (2012). A new paradigm for the learning of a second or foreign language: The neurolinguistic approach, Neuroeducation, 1(1), 85-114.

[20] Paradis, M. (1994). Neurolinguistic aspects of implicit and explicit memory: implications for bilingualism. In N. Ellis, Implicit and Explicit Learning of Second Languages. (pp. 393-419). London: Academic Press.

[21] Robert B. Dilts R. B., Delozier A. J.(2000) Encyclopedia of Systemic Neuro-Linguistic Programming and NLP New Coding, Santa Cruz (CA): NLP University Press.

[22] Squirrel L. (2008). Can Neuro-Linguistic Programming work with young children who display varying Social, Emotional and Behavioural Difficulties?. In P. Tosey (ed.), Current research in NLP; vol. 1: proceedings of the first international NLP research conference, University of Surrey, 5th July 2008, South Mimms, Hertfordshire: ANLP International CIC.

[23] Takeuchi E., Kageura R. \& Takahashi K. (2016). L'approche neurolinguistique (ANL), en tant qu'enseignement fondé sur les neurosciences et la littératie, dans les universités japonaises. Actes de la Conférence Internationale sur le Français (CIF). Le français: enjeux linguistiques, politiques, économiques, et culturels. Retrieved from http://upipress.u pi.edu/assets/file/11_Prosiding_France.pdf

[24] Thiry A. (2012). Ca y est j’ai compris!. Louvain-la-Neuve: de Boeck.

[25] Vygotsky, L.S. (1997). Pensée et langage. Paris: Éditions La Dispute.

[26] Vygotsky, L.S. (1978). Mind in Society. Cambridge, MA: Harvard University Press. 